\title{
A pilot-scale test on the treatment of biological pretreated leachate by the synergy of ozonation-biological treatment-catalytic ozonation
}

\author{
Yuanmei Chen ${ }^{1}$, Yutang Xiao ${ }^{{ }^{\dagger}}$, Guanping Wang ${ }^{2}$, Wei $\mathrm{Shi}^{2}$, Linquan $\mathrm{Sun}^{3^{\dagger}}$, Yanfang $\mathrm{Chen}^{3}$, \\ Aichun Miao ${ }^{3}$ \\ ${ }^{1}$ School of Environment, South China Normal University, Guangzhou 510006, China \\ ${ }^{2}$ Everbright Water (Shenzhen) Co., Ltd., Shenzhen 518000, China \\ ${ }^{3}$ Shenzhen Changlong Technology Co., Ltd., Shenzhen 518000, China
}

\begin{abstract}
In this pilot-scale test, the ozonation-biological treatment-catalytic ozonation system was performed to treat complex organics and highly-concentrated total nitrogen $(\mathrm{TN})$ in biological pretreated incineration leachate. The test results showed that the ratio of five-day biochemical oxygen demand $\left(\mathrm{BOD}_{5}\right)$ / chemical oxygen demand (COD) increased from 0.059 to 0.237 , which indicated that the concentration of biodegradable $\mathrm{COD}\left(\mathrm{COD} \mathrm{Dio}_{\text {bio }}\right.$ increased by ozonation pre-treatment process. In addition, the TN removal mainly occurred in anaerobic zone due to direct denitrification by the activated bacteria, which were domesticated through different influent ratio. Moreover, it was necessary to add catalytic ozonation process to reach higher direct effluent discharge criteria. After 60 days repeated debugging, the removal rate of COD and TN reached $88.5 \%$ and $98.2 \%$, respectively. Finally, the total cost of this system was $¥ 6.65 / \mathrm{m}^{3}\left(\$ 0.95 / \mathrm{m}^{3}\right)$, which was acceptable for the treatment of biological pretreated leachate. This pilot-scale test could provide some guiding information for the treatment of leachate containing highly-concentrated TN with low $\mathrm{COD}_{\text {bio }} / \mathrm{N}$ by the composite system.
\end{abstract}

Keywords: COD removal, Composite system, Incineration leachate, TN removal

\section{Introduction}

Incineration has been an effective technology of municipal solid waste (MSW) disposal for its advantages in reducing approximately $90 \%$ of the volume and $75 \%$ of the mass from MSW, energy production and saving space [1, 2]. The fresh MSW in general needs to be held for 3-7 days before incineration to remove its high moisture content, but unfortunately a considerable amount of fresh leachate can be produced during this period [3]. Leachate will be generated by liquid from solid wastes, which has high contaminant concentrations [4]. Thus, incineration leachate is a complex wastewater which contains a large amount of biodegradable organic, refractory organics, heavy metals, ammonia and many other toxic matters $[5,6]$. In conventional engineering applications, biological treatment followed by membrane separation technique such as membrane bio-reactor (MBR), reverse osmosis (RO), nanofiltration (NF) and ultrafiltration (UF), they had been widely applied in the treatment of leachate [7]. Since the majority of easily biodegradable organics in leachate are removed through the above-mentioned combined process, most of the remaining matters are made of humic substances with aromaticity and macromolecular weight which lead to low biodegradability $\left(\mathrm{BOD}_{5} / \mathrm{COD}<0.1\right)$. At present, the main treatment technology of biological pretreated and membrane separated leachate are the recirculation and advanced oxidation processes (AOPs) $[8,9]$. However, the recirculation of leachate may inhibit the microbial activity and affect the performance of membrane separation process due to the high concentrated organics and heavy metals $[10,11]$. And if lots of organic matters and heavy metals in incineration leachate are not treated properly, they would pollute surface water, groundwater, and change soil quality. Therefore,
This is an Open Access article distributed under the terms of the Creative Commons Attribution Non-Commercial License (http://creativecommons.org/licenses/by-nc/3.0/) which permits unrestricted non-commercial use, distribution, and reproduction in any medium, provided the original work is properly cited.
Received June 21, 2020 Accepted August 15, 2020

${ }^{\dagger}$ Corresponding author

Email: 1712208542@qq.com, myth619@163.com

Tel: + 020-39313366 Fax: + 020-39313366 
it is urgent to explore appropriate technologies to treat incineration leachate [12].

According to the previous studies, some methods have been used to treat leachate, such as electrochemical oxidation [13, 14], Fenton process [15-17], ozone-based advanced oxidation process $[18,19]$, etc. Electrochemical oxidation although having versatility, high efficiency and environmental compatibility in handling leachate, have shortcomings of being energy-intensive process and high operating costs [20]. Fenton process could effectively degrade organics via powerful oxidizing agents. However, it also has shortcomings such as the generation of iron sludge and narrow $\mathrm{pH}$ range between $\mathrm{pH}$ 2-3 [18, 20]. Compared with the above-mentioned methods for the leachate, ozonation has wide engineering application in wastewater because of its excellent oxidation capacity and no secondary pollution property [21]. Ozone molecules, ozone self-decomposing hydroxyl radicals $(\cdot \mathrm{OH})$ or a combination of $\mathrm{O}_{3}$ and -OH can react with refractory organics [22, 23]. Overall $1.5 \mathrm{~mol}$ of $\mathrm{O}_{3}$ could produce $1 \mathrm{~mol}$ of $\cdot \mathrm{OH}$ [24]. According to standard oxidation potentials, $\cdot \mathrm{OH}\left(\mathrm{E}^{0}=2.8 \mathrm{v}\right)$ with excellent reaction rate constants of $10^{6}-10^{9} \mathrm{M}^{-1} \mathrm{~S}^{-1}$ is stronger oxidant than molecular ozone $\left(\mathrm{E}^{0}=2.08 \mathrm{v}\right)$, which has the ability to oxide the complex organics, especially the humic substances [25, 26]. Ozonation process alters the molecular structure of refractory compounds and oxide them to more biodegradable compounds used as carbon source for the denitrification in subsequent biological treatment [18, 20]. Therefore, ozonation is an effective approach as pre-treatment of leachate to improve biodegradability. Catalyst can be an addon to accelerate reaction in ozonation. Catalytic ozonation can effectively remove organic compounds since catalysts promote surface reactions between the adsorbed ozone and pollutants. To meet stricter effluent discharge criteria, catalytic ozonation further degrade organic pollutants as post-treatment. H. Wang [19] showed that micro-ozonation could achieve $76.0 \%$ COD and $69.9 \%$ TOC (Total Organic Carbon) removal for the further treatment of refractory substances in leachate under optimal conditions.

It has been observed that AOPs combined with biological treatment for the leachate could reach direct effluent discharge criteria. The biological treatments are the common technique for removing nitrogen owing to the simplicity and cost-effectiveness [27]. The existing nitrogen removal processes are mainly including conventional nitrification-denitrification, nitritation-denitritation and anammox process, etc [28]. F.N. Ahmed [29] found that denitrification-partial nitrification-anammox process could utilize $\mathrm{COD}_{\text {bio }}$ in wastewater to achieve the $\mathrm{NO}_{3}^{-}-\mathrm{N}$ removal, and was also beneficial for the growth of autotrophic bacteria. Z. Wang [30] reduced the $\mathrm{NO}_{3}^{-}-\mathrm{N}$ through partial denitrification-anammox process. However, there are few studies about the engineering application of ozonation-biological treatment-catalytic ozonation for the biological pretreated and membrane separated leachate.

The typical characteristics of the biological pretreated and membrane separated leachate from this test are macromolecular (organic matters), highly-concentrated (total nitrogen) and refractory (low biodegradability). Therefore, this pilot-scale test devoted to degrading macromolecular organic matters and removing highly-concentrated TN by the synergy of ozonation-biological treatment-catalytic ozonation. Especially the main purpose of the test is to remove TN due to the low $\mathrm{COD}_{\mathrm{bio}} / \mathrm{N}$ ratio in leachate, which is the most challenging part of this pilot-scale test. In this work, ozonation was selected as the pre-treatment process to decompose macromolecular organic contaminants into biodegradable one and increase the $\mathrm{COD}_{\text {bio }} \mathrm{N}$ ratio, which was beneficial for the subsequent nitrogen removal in the biological process. Then in the biological process, nitrogen was removed by activated bacteria using organic carbon as electron donor and nitrate as electron acceptor. At the end, to further optimize the effluent, catalytic ozonation was used to deeply remove organic pollutants. The pilot-scale test will provide useful information for full-scale practical implementation.

\section{Material and Methods}

\subsection{The Raw Water}

The raw water used in this test was got from an MSW incineration power plant in the Everbright Environmental Energy (Nanjing) Co., Ltd., China. The water samples were collected after biological pretreatment and ultrafiltration separated process. The characteristics of the raw water are shown in table 1 . Values are given as an average.

Table 1. Initial Characteristics of Wastewater

\begin{tabular}{lccc}
\hline Parameters & Values & Parameters & Values \\
\hline $\mathrm{COD}(\mathrm{mg} / \mathrm{L})$ & $389-513$ & Color & Dark brown \\
$\mathrm{NH}_{4}{ }^{+}-\mathrm{N}(\mathrm{mg} / \mathrm{L})$ & $16.5-22.3$ & Smell & light \\
$\mathrm{NO}_{3}{ }^{-}-\mathrm{N}(\mathrm{mg} / \mathrm{L})$ & $850-960$ & $\mathrm{~B} / \mathrm{C}$ ratio & 0.059 \\
$\mathrm{TN}(\mathrm{mg} / \mathrm{L})$ & $1070-1200$ & $\mathrm{pH}$ & $7-8$ \\
\hline
\end{tabular}

\subsection{Materials}

Activated bacteria (a milky liquid, cfu > ten billion per milliliter) and composite carbon source (a dark brown liquid, smell aromatic) were provided by Shenzhen Changlong Technology Co., Ltd., China.

\subsection{Experimental Procedures}

Based on the property of raw water, the pilot-scale setup (Fig. 1) including ozone and biological system was designed, and the related research results were tested in laboratory. The ozone system was consisted of ozone generator $\left(1 \mathrm{~kg} \mathrm{O}_{3} / \mathrm{h}\right)$, ozonation reaction column (with a diameter of $0.5 \mathrm{~m}$ and a height of $2 \mathrm{~m}$ ), catalytic ozonation reaction chamber $\left(2 \mathrm{~m}[\mathrm{~L}]^{\prime} 0.5 \mathrm{~m}[\mathrm{~W}]^{\prime} 2 \mathrm{~m}[\mathrm{H}]\right)$, ozone exhaust destructor, and ozone analyzer (read ozone concentration in real time). The biological system was composed of backwashing pump, reflux pump, agitator and aerator, containing anaerobic zone $\left.\left(0.3 \mathrm{~m}[\mathrm{~L}]^{\prime} 1.4 \mathrm{~m} \mathrm{[W]}\right]^{\prime} 2.1 \mathrm{~m} \mathrm{[H]}\right)$, anoxic zone (0.5 $\left.\mathrm{m}[\mathrm{L}]^{\prime} 0.5 \mathrm{~m} \mathrm{[W]}{ }^{\prime} 2 \mathrm{~m} \mathrm{[H]}\right)$, aerobic zone (0.4 m [L] ${ }^{\prime} 0.5 \mathrm{~m}$ [W] ' $2 \mathrm{~m}[\mathrm{H}]$ ), and ceramic membrane separation zone (1 $\mathrm{m} \mathrm{[L]}$ ' $\left.0.5 \mathrm{~m}[\mathrm{~W}]^{\prime} 2 \mathrm{~m}[\mathrm{H}]\right)$. Ozone was generated from oxygen conversion in ozone generator and simultaneously entered to the ozonation reaction column. The raw water was pre-treated by ozonation and then entered to the biological treatment system. After the anaerobic, the anoxic and the aerobic treatment, the sewage returned or entered to ceramic membrane pool. Finally, in order to attain higher direct effluent discharge criteria, the membrane effluent would be treated 


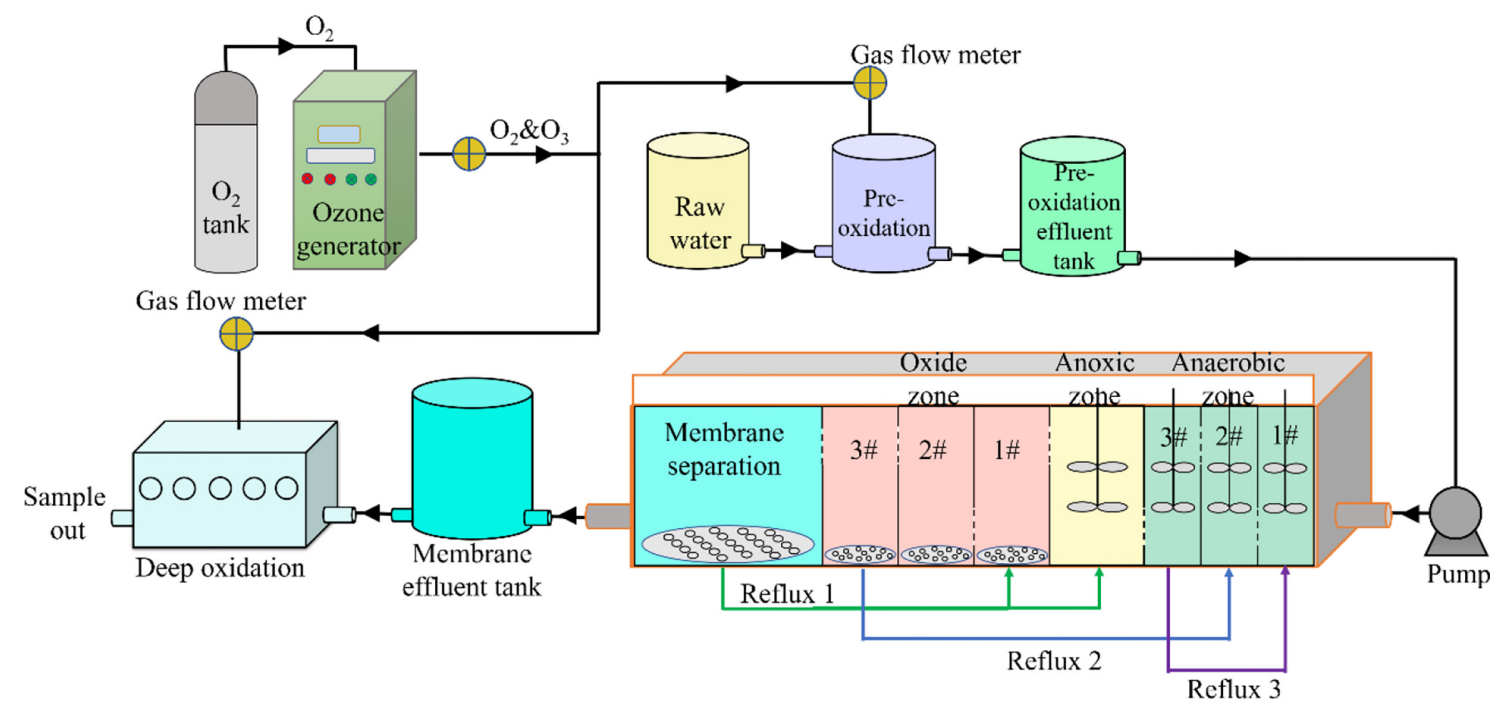

Fig. 1. Experimental apparatus for pilot-scale test.

by catalytic ozonation. In the biochemical system, three backflow paths were set up. Reflux 1: from the ceramic membrane pool to aerobic pool 1 and anoxic pool, the sludge with influent flow to the ceramic membrane pool was returned back to the front end, which at the same time diluted the influent, increased the sludge concentration and the processing capacity of aerobic pool 1 and anoxic pool. Reflux 2: from the aerobic pool 3 to anaerobic pool 2, the process improved the denitrification. Reflux 3: from anaerobic pool 3 to anaerobic pool 1, the anaerobic sludge that came with the influent to anaerobic pool 3 would return to the front end, and the anaerobic wastewater would be diluted, simultaneously the sludge concentration and the processing capacity of anaerobic pool 1 would be enhanced.

\subsection{Inoculated Sludge}

The activated sludge used in the test was got from in the aerobic pool of MSW incineration power plant. The initial concentration of mixed liquor suspended solids (MLSS), mixed liquor volatile suspended solid (MLVSS) and sludge volume index at $30 \mathrm{~min}$ $\left(\mathrm{SVI}_{30}\right)$ of activated sludge were $5.0 \mathrm{mg} / \mathrm{L}, 3.5 \mathrm{mg} / \mathrm{L}, 75 \%$, respectively. The method of inoculated sludge of different zones in the biological system was as follows: the sludge and leachate were fully mixed at a volume ratio of $3: 20$, and then was poured into biological zones. According to the $\mathrm{COD}_{\text {bio }}: \mathrm{N}=6: 1$, homemade synthetic carbon source were added to increase electron donor in the anaerobic zone for the inoculation of activated bacteria provided by Shenzhen Changlong Technology Co., Ltd., China. The activated bacteria were cultured to remove $\mathrm{TN}$ in anaerobic zone. The regular dosage of activated bacteria is $10 \mathrm{~g} / \mathrm{m}^{3}$, and 3 times of the regular dosage should be required for the first 3 days. Then add activated bacteria continuously for 7 days according to the regular dosage. The aerobic bacteria were cultured under complete aeration in the aerobic zones. The concentration of DO in the aerobic zone was controlled to be $2 \mathrm{mg} / \mathrm{L}$ at room temperature. $\mathrm{pH}$ of system was stable at 7-8. In order to adapt highly-concentrated TN caused by leachate concentrates, the biological system was performed by three stages. The system took sequential batch influent, the proportion of feed water was $15 \%, 25 \%$ and $41 \%$, respectively.

\subsection{Analytical Methods}

The COD, $\mathrm{NH}_{4}{ }^{+}-\mathrm{N}, \mathrm{NO}_{3}{ }^{-} \mathrm{N}, \mathrm{TN}, \mathrm{MLSS}, \mathrm{MLVSS}$ and $\mathrm{SV}_{30}$ were measured according to the standard methods [31]. The $\mathrm{pH}$ was measured using a $\mathrm{pH}$ meter (pHBJ-261L, Shanghai Scientific Instrument Co., Ltd., china). The DO was measured using a DO meter (BDO-7500, BELL Analytical Instrument (Dalian) Co., Ltd., china).

\section{Results and Discussion in Different Stages}

\subsection{Ozonation Stage}

As a promising method, Ozonation is suitable for leachate pre-treatment, which could improve the biodegradability and reduce wastewater toxicity. In this stage, the macromolecular organics are broken into easily biodegradable smaller ones by ozonation pre-treatment to increase the concentration of $\mathrm{COD}_{\text {bio }}$ as carbon source for subsequent denitrification in wastewater [32]. As shown in Fig. 2 (a), this process improved the biodegradability, with $\mathrm{B} / \mathrm{C}$ average rising from 0.059 to 0.237 , laying a foundation for subsequent biological system [33, 34]. The parameters of ozonation are mainly decided by adjusting the influent flow, power of ozone generator and gas flow, changing the water retention time and ozone dosage.

The influent flow of ozonation pre-treatment was $0.2 \mathrm{~m}^{3} / \mathrm{h}$, the total gas flow was controlled to $0.5 \mathrm{~m}^{3} / \mathrm{h}$, the gas flow of pre-treatment was designed to $0.3 \mathrm{~m}^{3} / \mathrm{h}$, the power of ozone generator was adjusted to obtain different ozone concentration and the corresponding ozone dosage would change. After half a month of repeated debugging, the test results are shown in Fig. 2 (b). The results demonstrated that the average removal rate of COD gradually increased, after increasing to a certain degree then would not obviously increase. 
In preliminary experiment, with the increasement of ozone dosage, the ability of directly oxidizing organic pollutants by ozone molecule was increased. Meanwhile the $\bullet \mathrm{OH}$ (indirect oxidation) produced from the decomposition of ozone was also increased. This observation was similar to some report [35-37] that the degradation efficiency of organics increases with increasing ozone concentration. The ozone dosage increased from $120 \mathrm{mg} / \mathrm{L}$ to 132 $\mathrm{mg} / \mathrm{L}$, but the COD removal rate was not increased obviously due to the saturation of the aqueous ozone $[38,39]$. In saturated stage, it was at equilibrium between the consumption and supply, the increasement of ozone concentration was redundant. It is worth noting that Barbara Kasprzyk-Hordern et al. [40] found that the degradation ability of organic contaminants would reduce for the reaction between the excessive amount of ozone and free radicals. Thus, the experiment selected $120 \mathrm{mg} / \mathrm{L}$ as the ozone dosage. In ozonation stage, the COD removal rate was no longer increased at about $38.8 \%$, which was similar to the research [41]. The reason for the low efficiency was that the small decrease of COD, which was affected by the organic contaminant mineralization. And it is obvious that complete oxidation for the raw water containing highly-concentrated $\mathrm{NO}_{3}{ }^{-}-\mathrm{N}$ in this pilot-scale test is inappropriate, but partial oxidation destroying original macromolecular organic structure is beneficial by reducing toxicity and enhancing biodegradable organics as carbon source in subsequent biological treatment [37]. In the ozonation pre-treated process, when the ozone dosage was $120 \mathrm{mg} / \mathrm{L}$, the COD concentration change in the influent and effluent is shown in Fig. 2 (c), the average COD of influent and effluent were $450 \mathrm{mg} / \mathrm{L}, 279 \mathrm{mg} / \mathrm{L}$, respectively.

The average changes of $\mathrm{NH}_{4}{ }^{+}-\mathrm{N}, \mathrm{NO}_{3}^{-}-\mathrm{N}$ and $\mathrm{TN}$ during ozonation pre-treated process are shown in Fig. 3. After the ozonation process, the results showed increasing $\mathrm{NO}_{3}{ }^{-} \mathrm{N}$, slightly decreasing $\mathrm{NH}_{4}{ }^{+}-\mathrm{N}$ and almost unchanged TN. In pre-treated process, a small amount of ammonia nitrogen could be oxidized to the nitrate nitrogen, and the nitrate nitrogen in ozone environment was mainly from the oxidation of the nitrite nitrogen, so the nitrate nitrogen increased obviously; In the case of strong oxidation, the radicals produced by ozonation potentially resisted ammonification from organic nitrogen, and a small amount of ammonia nitrogen may be oxidized to nitric nitrogen, the combination of both would reduce the concentration of ammonia nitrogen, therefore the trend of ammonia nitrogen was lightly decreasing [42]. The ozonation process couldn't remove nitrogen, which led to almost unchanged TN.

\subsection{Biological Stage}

Aiming to treat the highly-concentrated $\mathrm{NO}_{3}{ }^{-}-\mathrm{N}$ wastewater, direct denitrification is an economical method [30], so the experiment focused on controlling denitrification conditions and guaranteed sludge reflux in time among the zones. In this stage, the influent was fed into anaerobic zone to remove nitrogen by direct denitrification; the organic nitrogen in wastewater would be converted into $\mathrm{NH}_{4}{ }^{+} \mathrm{-}$ by amination in the anoxic zone, and then were removed by nitrification in aerobic zone; the remaining organic pollutants would degrade in aerobic zone.

The system inoculated bacteria by three different influent proportion of $15 \%, 25 \%$ and $41 \%$ [29, 43]. After three different influent ratios debugging, yellowish-brown sludge and larger flocs were observed, the sedimentation performance was better than before.
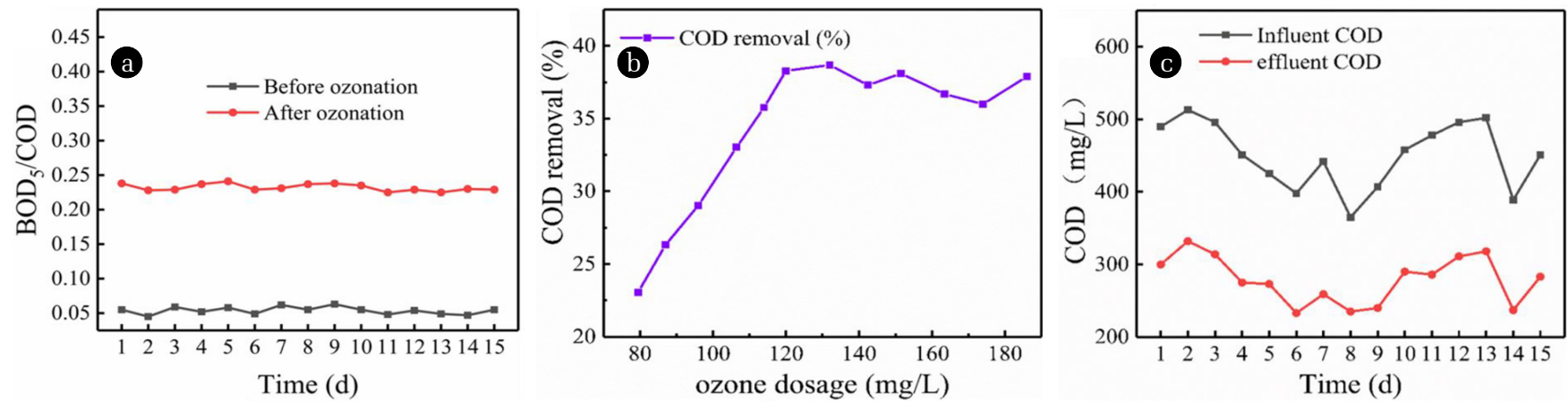

Fig. 2. Organics change in ozonation process: (a) B/C change, (b) COD removal rate, (c) COD change.
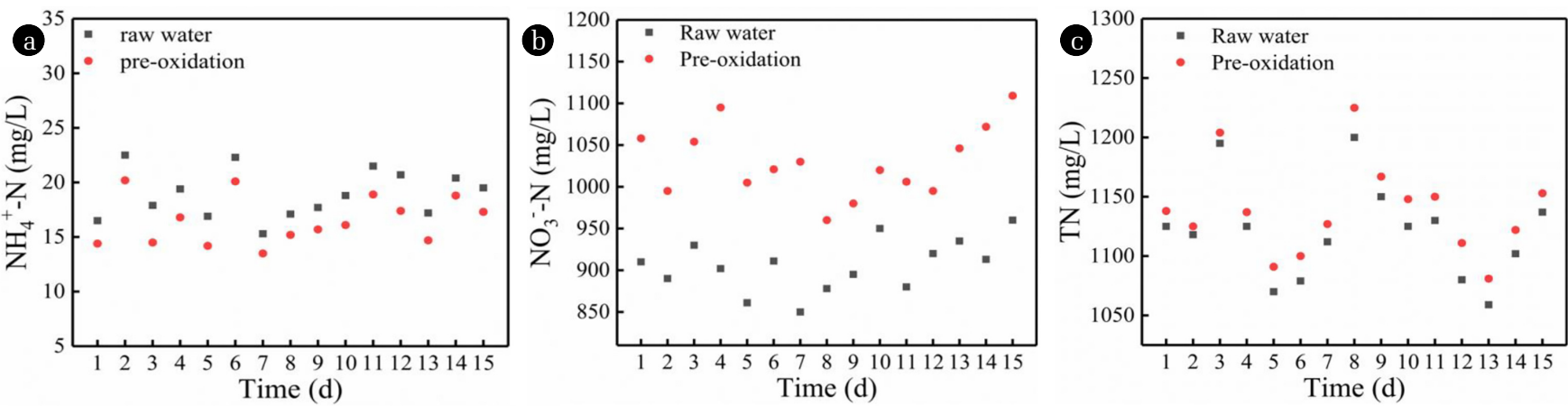

Fig. 3. The changes of nitrogen in ozonation process: (a) $\mathrm{NH}_{4}{ }^{+}-\mathrm{N}$, (b) $\mathrm{NO}_{3}^{-}-\mathrm{N}$, (c) $\mathrm{TN}$. 

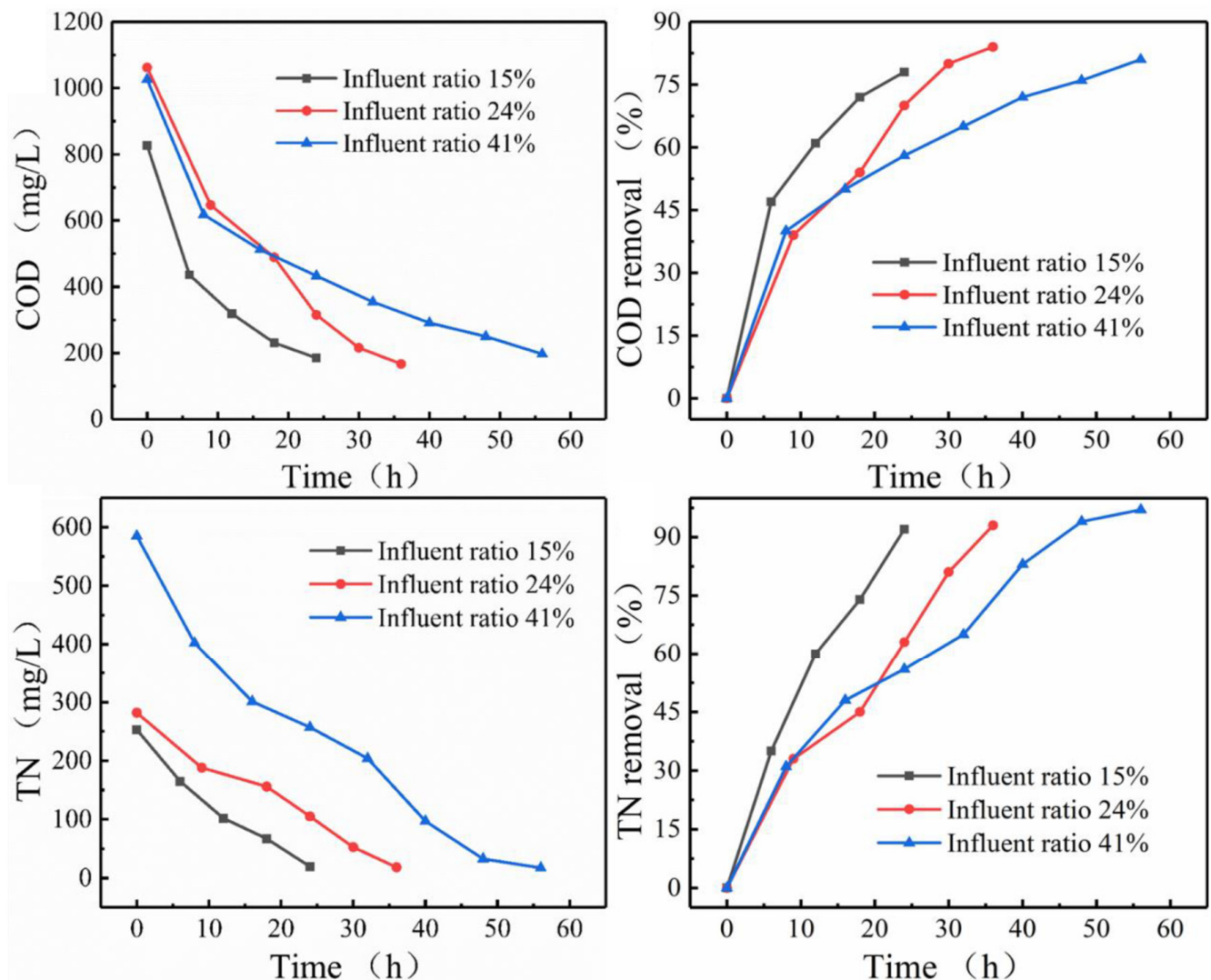

Fig. 4. The change of (COD and $\mathrm{TN}$ ) and (COD and $\mathrm{TN}$ ) removal in the biological process by different influent ratio: (a) COD change, (b) COD removal change, (c) TN change, (d) TN removal change.

During the debugging, the influent ratio of $15 \%, 24 \%$ and $41 \%$ were tested, respectively. And the results were almost the same after operating with $24 \mathrm{~h}, 36 \mathrm{~h}$ and $56 \mathrm{~h}$, respectively. The changes of COD and COD removal are shown in Fig. 4 (a) and (b). In Fig. 4 (a), the initial COD values are high because of the external carbon source. However, because the homemade carbon source was easily decomposed later, the COD could be controlled (less than 200 $\mathrm{mg} / \mathrm{L}$ ). At the stage of $15 \%$ influent ratio, the system took $24 \mathrm{~h}$ to achieve the expected result (COD was less than $200 \mathrm{mg} / \mathrm{L}$ ). According to this method, when the system influent ratio was $25 \%$ and $41 \%$, it would take $38.4 \mathrm{~h}$ and $65.6 \mathrm{~h}$ to obtain the similar result (COD was less than $200 \mathrm{mg} / \mathrm{L}$ ). Surprisingly, the actual time to obtain the similar result was less than the theoretical time, and it just took $36 \mathrm{~h}$ and $56 \mathrm{~h}$ to reach the result when the influent ratios were $25 \%$ and $41 \%$, respectively. This was because the low concentration of MLSS in the initial domesticated stage [43]. With the increase of influent ratio, the whole system gradually became mature and tended to be steady. After debugging, the sludge activity reached its optimum state (MLSS: $8.62 \mathrm{~g} / \mathrm{L}, \mathrm{MLVSS}: 6.87 \mathrm{~g} / \mathrm{L}, \mathrm{SV}_{30}$ : 55\%), which had enough microorganisms to degrade organic contaminants. At the stable stage, the effluent COD average concentration was about $183 \mathrm{mg} / \mathrm{L}$, the COD average removal obtained 81\%.

As shown in Fig. 4 (c) and (d), with the influent ratio of 15\%, $24 \%$ and $41 \%$, the TN concentration obtains the similar results (TN: $15-20 \mathrm{mg} / \mathrm{L}$ ) after operating the system by $24 \mathrm{~h}, 36 \mathrm{~h}$ and
$56 \mathrm{~h}$, respectively [44]. The removal of TN was correlated with the denitrification efficiency. At the initial debugging, the most prominent feature was the insufficiency of biodegradable organic matter. The biodegradable organic matters would be increased with the increase of influent ratio, which added denitrification electron donor [43]. With the increase of denitrification efficiency, the system would take less time to achieve the anticipated result (TN was less than $20 \mathrm{mg} / \mathrm{L}$ ). The result was consistent with the report that the effluent TN was less than $20 \mathrm{mg} / \mathrm{L}$ by partial denitrification-anammox process [30].

Because the debugging was in accordance with the different influent ratio, the ammonia oxidation, nitrification and denitrification had achieved good results in the biological system. Therefore, according to the above method, the influent flow of the biological system with $1120 \mathrm{mg} / \mathrm{L}$ TN was designed to be $0.2 \mathrm{~m}^{3} / \mathrm{h}$. The whole biological system could run well by $100 \%$ influent ratio, the average COD of the effluent is remained within $200 \mathrm{mg} / \mathrm{L}$, and TN is about $15 \sim 20 \mathrm{mg} / \mathrm{L}$, which indicate the method is practical.

\subsection{Catalytic Ozonation Stage}

Some literatures have been shown that the heterogeneous catalytic ozonation is a promising process for the degradation of refractory organic matters in post-treatment [45-47]. Therefore, the system selected a Fe-Cu/ $\gamma-\mathrm{Al}_{2} \mathrm{O}_{3}$ (with a diameter of $6-8 \mathrm{~mm}$, BrunnerEmmet-Teller (BET) surface area was about $164.2 \mathrm{~m}^{2} / \mathrm{g}$ ) composite 


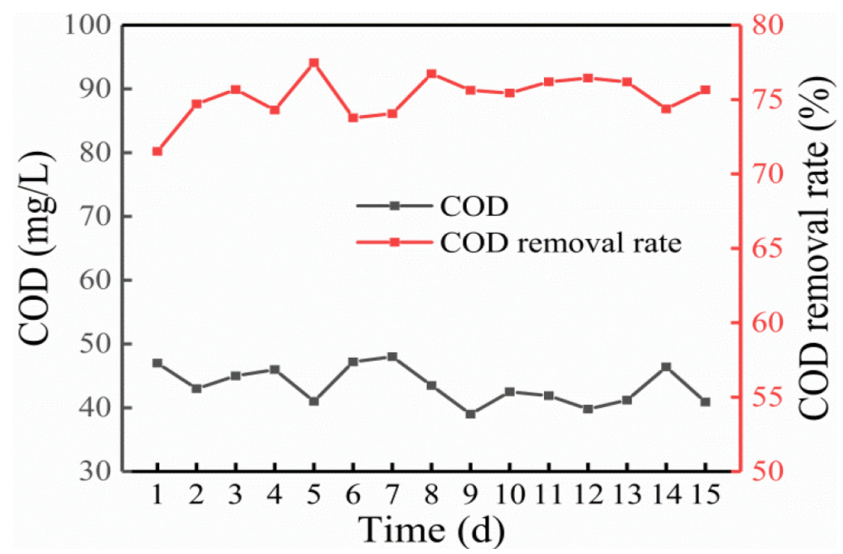

Fig. 5. The COD effluent concentration and the removal rate in catalytic ozonation process.

as catalyst to enhance removal efficiency. In this process, the gas flow was assigned to $0.2 \mathrm{~m}^{3} / \mathrm{h}$ and the ozone dosage was $80 \mathrm{mg} / \mathrm{L}$, which was consistent with ozonation debugging. As shown in Fig. 5 , the effluent COD is controlled within $50 \mathrm{mg} / \mathrm{L}$. With the addition of $50 \mathrm{~kg} / \mathrm{m}^{3}$ catalyst (the amount of catalyst was calculated by the result of laboratory test), $75.2 \%$ COD was removed. The ozone dosage was affected by the addition of the catalyst: when the pre-oxidation ozone dosage was $120 \mathrm{mg} / \mathrm{L}$, the average COD removal rate was $38.8 \%$; however, the COD removal rate reached to $75.2 \%$ when catalytic oxidation ozone dosage was $80 \mathrm{mg} / \mathrm{L}$. This was because ozone and organic pollutants could be adsorbed on the catalyst's surface, and then generated the $\mathrm{HO}_{3}{ }^{-}$and $\cdot \mathrm{OH}$ to degrade contaminants. As a result, the removal rate was doubled by using less ozone dosage due to the adsorption and catalytic ozonation.

\subsection{Economic Analysis}

The cost of this test mainly included ozone, electric power and catalyst. With $40 \mathrm{~g} / \mathrm{h}$ ozone dosage and $0.2 \mathrm{~m}^{3} / \mathrm{h}$ influent flow, the ozone dosage of this system was calculated to be $40(\mathrm{~g} / \mathrm{h}) /$ $0.2\left(\mathrm{~m}^{3} / \mathrm{h}\right)=0.2 \mathrm{~kg} / \mathrm{m}^{3}$. The ozone production price was about $¥ 11.1 / \mathrm{kg}$ (\$1.58/kg). Therefore, the ozone cost was $¥ 2.21$ $/ \mathrm{m}^{3}$ (\$ $0.316 / \mathrm{m}^{3}$ ). The electric power consumption of various pumps, agitators, aerators and other devices was about $6.7 \mathrm{~kW} \times \mathrm{h} / \mathrm{m}^{3}$. According to the electric price ( $¥ 0.602 /(\mathrm{kW} \times \mathrm{h})$ ), the energy cost was about $¥ 4.06 / \mathrm{m}^{3}$ (\$ $0.58 / \mathrm{m}^{3}$ ). Including the additional cost (such as reagents, catalyst and water), the total cost of the system was about $¥ 6.65 / \mathrm{m}^{3}\left(\$ 0.95 / \mathrm{m}^{3}\right)$, which was acceptable for the treatment of incineration leachate UF concentrate. During the operation of these devices, the actual power was lower than the rated power, so the actual operating cost was slightly lower than this cost above. However, this was still a rough analysis, and it would be better to consider the personnel costs, maintenance and initial investment, etc.

\section{Conclusions}

In this pilot-scale test, the ozonation-biological treatment-catalytic ozonation system was performed to remove total nitrogen and organic matters from biological pretreated and membrane separated incineration leachate. Under the appropriate parameter conditions (influent flow of $0.2 \mathrm{~m}^{3} / \mathrm{h}$, total gas flow of $0.5 \mathrm{~m}^{3} / \mathrm{h}$, ozone dosage of $200 \mathrm{mg} / \mathrm{L}$ ), the effluent COD was less than $50 \mathrm{mg} / \mathrm{L}$. With the situation of high concentrated TN and low $\mathrm{C} / \mathrm{N}$, the experiment adjusted the influent ratio, simultaneously added composite carbon source and denitrifying bacteria, which ensure the effluent TN was lower than $20 \mathrm{mg} / \mathrm{L}$. After repeated debugging, the combined system obtained $88.5 \%$ COD removal rate and $98.2 \%$ TN removal rate, which met leachate discharge standards in China (GB16889-2008). And the total cost was about $¥ 6.65 / \mathrm{m}^{3}\left(\$ 0.95 / \mathrm{m}^{3}\right)$, which indicated that the system was practical in economics. Finally, the above-mentioned results indicated this combined system was more suitable for the treatment of refractory organics and highly-concentrated TN in leachate with a low $\mathrm{COD}_{\mathrm{bio}} \mathrm{N}$.

\section{Acknowledgment}

This work was financially supported by Shenzhen strategic emerging industry development special fund (JSGG20170823153043998).

\section{Author Contributions}

C.Y.M. (A graduate student) conducted all the experiments and wrote the manuscript. X.Y.T. (Professor) revised the manuscript. W.G.P (Researcher), S.W. (Researcher), S.L.Q. (Researcher), C.Y.F. (Researcher), and M.A.C. (Researcher) conducted some experiments.

\section{References}

1. Ye JX, Mu YJ, Cheng X, Sun DZ. Treatment of fresh leachate with high-strength organics and calcium from municipal solid waste incineration plant using UASB reactor. Bioresour. Technol. 2011;102:5498-5503.

2. Chou JD, Wey MY, Liang HH, Chang SH. Biotoxicity evaluation of fly ash and bottom ash from different municipal solid waste incinerators. J. Hazard. Mater. 2009;168:197-202.

3. Shi JY, Dang Y, Qu D, Sun DZ. Effective treatment of reverse osmosis concentrate from incineration leachate using direct contact membrane distillation coupled with a $\mathrm{NaOH} / \mathrm{PAM}$ pre-treatment process. Chemosphere 2019;220:195-203.

4. Bolyard SC, Reinhart DR. Evaluation of leachate dissolved organic nitrogen discharge effect on wastewater effluent quality. Waste Manage (Oxford). 2017;65:47-53.

5. Jiang F, Qiu B, Sun DZ. Degradation of refractory organics from biologically treated incineration leachate by $\mathrm{VUV} / \mathrm{O}_{3}$. Chem. Eng. J. 2019;370:346-353.

6. Liu XY, Shu ZF, Sun DZ, Dang Y, Holmes D. Heterotrophic Nitrifiers Dominate Reactors Treating Incineration Leachate with High Free Ammonia Concentrations. ACS Sustain. Chem. Eng. 2018;6:15040-15049.

7. Zhou B, Yu ZM, Wei QP, Long HY, Xie YN, Wang YJ. Electrochemical oxidation of biological pretreated and mem- 
brane separated landfill leachate concentrates on boron doped diamond anode. Appl. Surf. Sci. 2016;377:406-415.

8. He R, Wei XM, Tian BH, Su Y, Lu YL. Characterization of a joint recirculation of concentrated leachate and leachate to landfills with a microaerobic bioreactor for leachate treatment. Waste Manage (Oxford). 2015;46:380-388.

9. Chen WM, Luo YF, Ran G, Li QB. An investigation of refractory organics in membrane bioreactor effluent following the treatment of landfill leachate by the $\mathrm{O}_{3} / \mathrm{H}_{2} \mathrm{O}_{2}$ and MW/PS processes. Waste Manage (Oxford). 2019;97:1-9.

10. Robinson AH. Landfill leachate treatment. Membr. Technol. 2005;2005:6-12.

11. Calabrò PS, Sbaffoni S, Orsi S, Gentili E, Meoni C. The landfill reinjection of concentrated leachate: Findings from a monitoring study at an Italian site. J. Hazard. Mater. 2010;181:962-968.

12. Jiang F, Qiu B, Sun DZ. Advanced degradation of refractory pollutants in incineration leachate by UV/Peroxymonosulfate. Chem. Eng. J. 2018;349:338-346.

13. Quan XJ, Cheng ZL, Chen B, Zhu XC. Electrochemical oxidation of recalcitrant organic compounds in biologically treated municipal solid waste leachate in a flow reactor. J. Environ. Sci. 2013;25:2023-2030.

14. Ren X, Song K, Xiao Y, Zong SY, Liu D. Effective treatment of spacer tube reverse osmosis membrane concentrated leachate from an incineration power plant using coagulation coupled with electrochemical treatment processes. Chemosphere 2020;244:125479.

15. Gu ZP, Chen WM, Li QB, Zhang AP. Treatment of semi-aerobic aged-refuse biofilter effluent from treating landfill leachate with the Fenton method. Process Saf. Environ. Prot. 2020;133:32-40.

16. Hu YM, Lu YB, Liu GL, Luo HP, Zhang RD, Cai XF. Effect of the structure of stacked electro-Fenton reactor on treating nanofiltration concentrate of landfill leachate. Chemosphere. 2018;202:191-197.

17. He R, Tian BH, Zhang QQ, Zhang HT. Effect of Fenton oxidation on biodegradability, biotoxicity and dissolved organic matter distribution of concentrated landfill leachate derived from a membrane process. Waste Manage (Oxford). 2015;38:232-239.

18. Wang HW, Wang YN, Li XY, Sun YJ, Wu H, Chen DL. Removal of humic substances from reverse osmosis (RO) and nanofiltration (NF) concentrated leachate using continuously ozone generation-reaction treatment equipment. Waste Manage (Oxford). 2016;56:271-279.

19. Wang H, Wang YH, Lou ZY, Zhu NW, Yuan HP. The degradation processes of refractory substances in nanofiltration concentrated leachate using micro-ozonation. Waste Manage (Oxford). 2017;69:274-280.

20. Gautam P, Kumar S, Lokhandwala S. Advanced oxidation processes for treatment of leachate from hazardous waste landfill: A critical review. J. Clean. Prod. 2019;237:117639.

21. Zhang JL, Xiong ZK, JA Wei, Song YH, Ren YZ, Xu DY, et al. Catalytic ozonation of penicillin $\mathrm{G}$ using cerium-loaded natural zeolite (CZ): Efficacy, mechanisms, pathways and toxicity assessment. Chem. Eng. J. 2020;383:123144.

22. Wang HW, Li XY, Hao ZP, et al. Transformation of dissolved organic matter in concentrated leachate from nanofiltration during ozone-based oxidation processes $\left(\mathrm{O}_{3}, \mathrm{O}_{3} / \mathrm{H}_{2} \mathrm{O}_{2}\right.$ and $\left.\mathrm{O}_{3} / \mathrm{UV}\right)$.
J. Environ. Manage. 2017;191:244-251.

23. Gunten UV. Ozonation of drinking water: Part I. Oxidation kinetics and product formation. Water Res. 2003;37:1443-1467.

24. Bila DM, Montalvão AF, Silva AC, Dezotti M. Ozonation of a landfill leachate: evaluation of toxicity removal and biodegradability improvement. J. Hazard. Mater. 2005;117:235-242.

25. Oguz E, Tortum A, Keskinler B. Determination of the apparent rate constants of the degradation of humic substances by ozonation and modeling of the removal of humic substances from the aqueous solutions with neural network. J. Hazard. Mater. 2008;157:455-463.

26. Gómez-Pacheco CV, Sánchez-Polo M, Rivera-Utrilla J, López-Peñalver J. Tetracycline removal from waters by integrated technologies based on ozonation and biodegradation. Chem. Eng. J. 2011;178:115-121.

27. Ahmed FN, Lan CQ. Treatment of landfill leachate using membrane bioreactors: A review. Desalination 2012;287:41-54.

28. Miao L, Yang GQ, Tao T, Peng YZ. Recent advances in nitrogen removal from landfill leachate using biological treatments A review. J. Environ. Manage. 2019;235:178-185.

29. Li X, Lu MY, Qiu QC, et al. The effect of different denitrification and partial nitrification-Anammox coupling forms on nitrogen removal from mature landfill leachate at the pilot-scale. Bioresour. Technol. 2020;297:122430.

30. Wang Z, Zhang L, Zhang FZ, et al. Enhanced nitrogen removal from nitrate-rich mature leachate via partial denitrification (PD)-anammox under real-time control. Bioresour. Technol. 2019;289:121615.

31. Association C, Washington D, A. P. H. A. : Standard Methods for the Examination of water and Wastewater. American Physical Education Review. 1995;24(9):481-486.

32. Qiao Y, Do A, Yeh D, Watts MJ. A bench-scale assessment of ozone pre-treatments for landfill leachates. Environ. Technol. 2014;35:145-153.

33. Chen WM, Zhang AP, Jiang GB, Li QB. Transformation and degradation mechanism of landfill leachates in a combined process of SAARB and ozonation. Waste Manage (Oxford). 2019;85:283-294.

34. Amaral-Silva N, Martins RC, Castro-Silva S, Quinta-Ferreira $\mathrm{RM}$, Ozonation and perozonation on the biodegradability improvement of a landfill leachate. J. Environ. Chem. Eng. 2016;4:527-533.

35. Huang YX, Cui CC, Zhang DF, Li L, Pan D. Heterogeneous catalytic ozonation of dibutyl phthalate in aqueous solution in the presence of iron-loaded activated carbon. Chemosphere. 2015;119:295-301.

36. Liu YF, Zhao JN, Li ZX, et al. Catalytic ozonation of bisphenol A in aqueous solution using Mn-Ce/HZSM-5 as catalyst. Water. Sci. Technol. 2015;72:696.

37. Somensi CA, Simionatto EL, Bertoli SL, Wisniewski A, Radetski CM. Use of ozone in a pilot-scale plant for textile wastewater pre-treatment: Physico-chemical efficiency, degradation by-products identification and environmental toxicity of treated wastewater. J. Hazard. Mater. 2010;175:235-240.

38. Yang ZY, Zhang YG, Zhu WJ, Zan XJ, Zhang LT, Liu YX. Effective oxidative degradation of coal gasification wastewater by ozonation: A process study. Chemosphere 2020;255. 
39. Cui YR, Wu Q, Xiao SN, An X, Sun JH, Cui FL. Optimum Ozone Dosage of Preozonation and Characteristic Change of Refractory Organics in Landfill Leachate. Ozone-Sci Eng. 2014;36:427-434.

40. Kasprzyk-Hordern B, Ziółek M, Nawrocki J. Catalytic ozonation and methods of enhancing molecular ozone reactions in water treatment. Appl. Catal., B. 2003;46:639-669.

41. Rivas FJ, Beltrán F, Gimeno O, Acedo B, Carvalho F. Stabilized leachates: ozone-activated carbon treatment and kinetics. Water Res. 2003;37:4823-4834.

42. Plósz BG, Ried A, Lopez A, Liltved H, Vogelsang C. Ozonation as a Means to Optimize Biological Nitrogen Removal from Landfill Leacate. Ozone-Sci. Eng. 2010;32:313-322.

43. Song JY, Zhang W, Gao JF, et al. A pilot-scale study on the treatment of landfill leachate by a composite biological system under low dissolved oxygen conditions: Performance and microbial community. Bioresour. Technol. 2020;296:122344.
44. Wang Z, Zhang L, Zhang FZ, et al. A continuous-flow combined process based on partial nitrification-Anammox and partial denitrification-Anammox (PN/A+PD/A) for enhanced nitrogen removal from mature landfill leachate. Bioresour. Technol. 2020;297:122483.

45. Wu ZW, Zhang GQ, Zhang RY, Yang FL. Insights into Mechanism of Catalytic Ozonation over Practicable Mesoporous $\mathrm{Mn}-\mathrm{CeOx} / \gamma-\mathrm{Al}_{2} \mathrm{O}_{3}$ Catalysts. Ind. Eng. Chem. Res. 2018;57: 1943-1953.

46. Ikhlaq A, Brown DR, Kasprzyk-Hordern B. Mechanisms of catalytic ozonation: An investigation into superoxide ion radical and hydrogen peroxide formation during catalytic ozonation on alumina and zeolites in water. Appl. Catal., B. 2013;129: 437-449.

47. Li CH, Jiang F, Sun DZ, Qiu B. Catalytic ozonation for advanced treatment of incineration leachate using $\left(\mathrm{MnO}_{2}-\mathrm{Co}_{3} \mathrm{O}_{4}\right) / \mathrm{AC}$ as a catalyst. Chem. Eng. J. 2017;325:624-631. 